be "in the interest of justice," encompasses far more than the criterion of convenience, and therefore prevents the escape of the defendant to a jurisdiction in which the plaintiff cannot afford to sue.41 And where the court grants transfer to a forum in which the plaintiff can afford to sue, the defendant cannot hide behind jurisdictional barriers since a prerequisite to transfer is another available forum. Nor is the plaintiff subject to any delay if he selects the convenient forum as original venue. ${ }^{42}$ Thus the new transfer provision of the Judicial Code, while protecting antitrust defendants from an harassing and vexatious choice of venue, still permits protection of the penniless private litigant from the evading tactics of a wealthy, well-represented corporate defendant.

\title{
COUNTERCLAIM FOR MALICIOUS PROSECUTION IN THE ACTION ALLEGED TO BE MALICIOUS*
}

IN an original action for malicious prosecution the plaintiff must alloge and prove the termination in his favor of a prior suit instituted maliciously and without probable cause; ${ }^{1}$ failure to allege the favorable termination of such a suit has uniformly been held to justify dismissal of the complaint."

have specifically applied the tests established in the Gulf Oil case. Ferguson v. Ford Motor Co., 77 F. Supp. 425 (S.D. N.Y. 1948) (antitrust treble damage suit, motion denied) ; SEC v. Wimer, 75 F. Supp. 955 (W.D. Pa. 1948) (SEC action, motion denied); Di Lella v. Lehigh Valley R.R., 7 F.R.D. 192 (S.D.N.Y. 1947) (negligence action, motion denicd).

41. It seems logical for courts to find that the "interest of justice" is not served by transferring a case beyond the reach of an impecunious plaintiff. Thus there seems little basis for the apprehension expressed in Note, 34 VA. L. REv. 811, 821 (1948), that $\$ 1404$ (a) will discourage the bringing of suits by such plaintiffs.

42. The delay involved in the filing and hearing of a motion to transfer, without appeal (see note 33 supra), will be short by its very nature. Furthermore, defendants failing to consolidate their motion to transfer with other pre-trial motions under FED. R. Clv. P. 12 (g) can well expect that the court will discredit their motives in the absence of a good reason for the lateness in making the motion.

* Herendeen v. Ley Realty Co., 75 N.Y.S. $2 d 836$ (Sup. Ct. 1947).

1. The elements of the cause of action are the same whether the prior suit be criminal or civil, the essence of the action being malice and lack of probable cause. Burt v. Smith, 181 N.Y. 1, 73 N.E. 495 (1905); Kolka v. Jones, 6 N.D. 461 , 71 N.W. 558 (1897); Glenn v. Lawrence, 280 Ill. 581, 117 N.E. 757 (1917). For a general treatment of the subject of malicious prosecution, see HARPER, LAW OF ToRTs \$\$268-271 (1933); Prosser, TORTS $\$ \S$ 96, 97 (1941).

2. Weber v. Strobel, 225 S.W. 925 (Mo. 1920); Martin v. Cedar Lake Ice Co., 145 Minn. 452, 177 N.W. 631 (1920). Actions for malicious prosecution, filed beforo the favorable termination of the suit alleged to be malicious, have been dismissed even though the suit had so terminated by the time of trial. Huffman v. Meriwether, 201 S.W. $2 \mathrm{~d} 460$ (Mo. App. 1947).

Authorities differ as to what constitutes termination of a civil suit, but the most general requirement is that the particular action be invulnerable to renewal. Graves v. Scott, 10.1 
On this ground, counterclaims of malicious prosecution when brought in the action alleged to be malicious similarly have been dismissed. ${ }^{3}$ A recent New York ruling, however, reaches a contrary result." The reasons for requiring an allegation of favorable termination, the court holds, are inapplicable to such a counterclaim.

The reasons for the favorable termination rule are clear. Termination of the prior suit removes the possibility of conflicting judgments should the plaintiff win the action for malicious prosecution and, subsequently, lose the original litigation. An unfavorable termination of the prior suit, moreover, establishes probable cause and bars a subsequent action for malicious prosecution. ${ }^{5}$

But an action for malicious prosecution filed as a counterclaim to the complaint in the particular suit alleged to be malicious entails no danger of conflicting judgments. And a court may order the issues peculiar to the counterclaim ${ }^{6}$ to be tried only after the favorable termination of a trial on the issues raised by the complaint. The ruling of the New York court,

Va. 372, 51 S.E. 821 (1905); Apgar v. Woolston, 43 N.J.L. 57 (1881). Malicious prosccution will not lie if the prior suit was terminated by compromise. Nelson v. National Casualty Co., 179 Minn. 53, 228 N.W. 437 (1929).

3. U.S. Tire Co. v. Kirk, 102 Kan. 418,170 Pac. $S 11$ (1918); Cawker City-State Banls v. Jennings, S9 Iowa 230, 56 N.W. 494 (1893); Niedringhaus v. Zuclser, 203 S.W.2d 211, (Mo. 1918); Friedman v. Roseth Corp., 190 Misc. 742, 74 N.Y.S.2d 733 (Sup. Ct. 1917). There appear to be no cases contra. Even where the plaintiff was a nonreident and dismissal of the counterclaim might deny the defendant all opportunity to pursue the action further, the counterclaim was held demurrable for lack of termination of the prior suit. Central Acceptance Corp. v. Rachal, 264 Ky. 849, 95 S.W. 2d 777 (1936).

4. Herendeen v. Ley Realty $C_{0}, 75$ N.Y.S. 2d 836 (Sup. Ct. 1947).

5. No action for malicious prosecution can, of course, be b3aed on procesdings which turn out to have been justified. See cases cited in Note, 69 A.L.R. 1062 (1930). Judgement for the plaintiff in the original civil action is usually conclusive of probable cause, even if reversed on appeal. Crescent City Livestock Co. v. Butchers' Union Slaughter-House Co., 120 U.S. 141 (1887); Clements v. Odorless Excavating Apparatus Co., 67 MId. 461, 605, 10 Atl. 412, 13 Atl. 632 (1887). There is an exception in the case of a judgment fradulently obtained. See cases cited in Note, 97 A.L.R. 1022 (1935). And favorable termination of the prior action need not be shown if it is one at which no opportunity was granted to contest the facts. Lanterman v. Delaware, L.\&W. R. Co., 229 F. 770 (D. N.J. 1916).

6. Peculiar to the counterclaim are the issues of malice and absence of probsble cause. Although evidence of absence of probable cause necessarily involves most of the facts relevant to the issues of the complaint, it also involves additional facts relevant to the reaconableness of the plaintiff's belief that he had a good cause of action. Stewart v. Sonneborn, 98 U.S. 187 (1878).

7. Modern codes with liberal counterclaim provisions are equally liberal in permitting the court to order separate trial of the counterclaim issues, if necessary. FEv. R. Clv. P., 42 (b); N.Y. Crv. PRAC. Acr \$ 262 (1939).

The issues irrelevant to the complaint in a counterclaim for malicious prosecution, should be tried separately. Were the issues of the complaint and counterclaim to be tried together, the danger exists that evidence of malice might prejudice the plaintiff's claim. Furthermore, should the plaintiff's claim fail, a court or jury which had heard all of the evidence at one time might be inclined to sustain the counterclaim as a matter of course. Yet the mere failure of the complaint under such circumstances should not in itself be evi- 
therefore, while it does not go so far as to permit the counterclaimant to cry before he is hurt, ${ }^{8}$ does allow him to complain before it is certain whether there is anyone to blame but himself. The counterclaim will not progress beyond the pleading stage, however, unless a successful determination of this issue gives the cause of action the matured status which would permit a separate suit. ${ }^{9}$

The New York ruling affords to the court and the respective partics an opportunity to dispose of an entire controversy in one action. Applied generally, it might produce other less desirable consequences.

Particularly in jurisdictions where an action for malicious prosecution may be based on almost any civil action ${ }^{10}$ and where relatively liberal provi-

dence of a lack of probable cause in bringing the suit. Barton v. Woodward, 32 Idaho 375, 182 Pac. 916 (1919).

8. Most of the damages which the counterclaimant hopes to recover have been in. curred before the filing of the counterclaim. Facile analogy to a person "about to be hit by a recklessly driven car," see Note, $25 \mathrm{Ky}$. L.J. 375 (1937), is, therefore, inaccurate. The defendant has been "hit," and the issue is the recklessness.

9. The New York court, seeking to surmount the metaphysical objection that a cause of action must be in existence when asserted, reasons that ". . . it is the malicious prosecution itself, and not the determination that the prosecution is malicious [and without probable cause?], which gives rise to the cause of action." 75 N.Y.S.2d 836, 838 (1947). Of course, an actual determination that the prior suit was malicious is not a prerequisite to the assertion of a valid cause of action as of the time a complaint or counterclaim asserting that cause of action is filed. But, at least heretofore, the actual favorable termination of the prior suit has been such a prerequisite. Since both malice and absence of probable cause are clearly essential to a successful cause of action for malicious prosecution, the court probably means no more than that the cause of action, if it can be established by subsequent proof of the facts necessary to sustain it, arises at the time the malicious complaint is filed. In effect, the court eliminates the favorable termination of the malicious suit as an essential element in the cause of action, though retaining it as a prerequisite to establishing absence of probable cause. But this reasoning taken alone would also permit a separate complaint, as well as a counterclaim, for malicious prosecution, to be filed before the termination of the allegedly malicious suit. It is probable, however, that the court would not follow its rationale to this conclusion; for to permit a separate claim pending disposition of the original proceeding entails no procedural advantage.

The court further suggests that its reasoning is supported by legislation, N.Y. Civ. PRAC. ACT $\S \S 266,245-a, 245-b$ (1939), abolishing the requirement that a counterclaim state a cause of action in existence at the time the complaint is filed. 75 N.Y.S. $2 \mathrm{~d} 836,838$ (1947). But these legislative provisions do not waive the requirement that a counterclaim state a cause of action, nor any requirement that the cause of action be in existence at tho time the counterclaim itself is filed. And similar legislation, Mo. R.S.A. $\$ 847.73$ (Supp. 1948), has been held of no avail for counter-claims for malicious prosecution. Niedringhaus v. Zucker, 208 S.W.2d 211 (Mo. 1948).

10. Many jurisdictions have been reluctant to permit malicious prosecution to bo brought for an ordinary civil suit, though a majority now do, and the remainder apparently allow the remedy when the civil suit involved interference with person or property, or when there was a series of harassing suits. Kolka v. Jones, 6. N.D. 461, 71 N.W. 558 (1897). Closson v. Staples, 42 Vt. 209, 1 Am. Rep. 316 (1869) (any civil action); Paul v. Fargo, 84 App. Div. 9, 82 N.Y.Supp. 369 (4th Dep't. 1903), Martin v. Rexford, 170 N.C. 540, 87 S.E. 352 (1915) (interference with person or property); Shedd v. Patterson, 302 11l. 355, 134 N.E. 705 (1922), Pangburn v. Bull, 1 Wend. 345 (N.Y. 1828) (successive suits). 
sion is made for counterclaims, ${ }^{11}$ a general application of the New York ruling might inhibit the litigation of bona fide claims. To file a counterclaim requires neither the time, the expense, nor the preparation required for the institution of a separate suit. More important, under the New York ruling, a counterclaim for malicious prosecution may be filed where an unfavorable termination of the action in which it is filed would forbid a separate suit. These considerations might be expected to induce more frequent claims of malicious prosecution, and, perhaps, to encourage meretricious counterclaims filed for their nuisance value alone. ${ }^{12}$ The increased prospect of a counterclaim may deter a potential plaintiff, who, particularly if he is impecunious or uncertain of his claim, may hesitate to incur the additional time and expense, and perhaps the need for separate counsel. ${ }^{13}$

A more serious threat to the potential plaintiff may result from a general application of the New York ruling if a court elects to try the issues of the complaint and counterclaim together, or if separate trial is had without a jury but before the same judge. An outcome of the complaint issues favorable to the defendant might make easier his task of proving the counterclaim issues of malice and absence of probable cause. The effect would be to vitiate the strict standard of proof required of an action for malicious prosecution, ${ }^{14}$ making more certain the recovery of damages. These damages are

11. While modern codes permit almost any cause of action to be pleaded as a counterclaim, some states have older codes which restrict a counterclaim to a cause of action arising out of the "contract" or out of the "transaction" set forth in the complaint, c.g." "The counterclaim ... must be one existing in favor of a defendant and against a plaintiff between whom a several judgment might be had in the action, and arising out of one of the following causes of action: 1.) A cause of action arising out of the contract or transaction set forth in the complaint as the foundation of the plaintiff's claim, or connected with the subject of the action. 2.) In an action arising on contract, any other cause of action arising also on contract, and existing at the commencement of the action." N.C. GE:s. Sr.1T. \$1-137 (1943). For an excellent summary see $C_{\text {LaRK, }}$ Code PLeiding, c. 10 (2d ed. 1917). A court in one of the latter states might view a counterclaim for malicious prosecution as arising out of a separate transaction, the prior suit itself, and hence disallow it.

12. In the alternative the worm may turn, and the harassed plaintiff bring an action for malicious prosecution because of the groundless counterclaim. Slee v. Simpson, 91 Colo. 461,15 P.2d 1084 (1932). Logically, the principle of the New Yorls ruling would permit this also to be brought in the original action, inviting in turn an additional counterclalm by the defendant. . . etc., etc.

13. Advice of counsel, acted upon after full and fair disclosure, is a complete defense to an allegation of lack of probable cause, even if the advice was erroneous. Hall v. Suydam, 6 Barb. 83 (N.Y. 1819); Brodrib v. Doberstein, 107 Conn. 29!, 140 Atl. 483 (1928); Anderson v. Snell, 57 Nev. 78, 62 P.2d 703 (1936). See Dorr Cattle Co. v. Des Mioines Nat. Banls, 127 Iowa 153, 98 N.W. 918 (1905); the disclosure must be complete, however, and the advice must be followed. Hepker v. Schmiclsle, 209 Iowa 744, 229 N.WY. 177 (1930); Note, 21 MINN. L. Rev. 217 (1937). Convincing proof that full disclosure was made and that counsel's advice was followed may require that counsel be sworn, maling him ineligible to participate as trial counsel on the issues of the counterclaim. 6 WIGsone, Evmexice $\$ 1911$ (3d ed. 1910). But of. Yeager v. Tomich, 68 N.E. 2d 110, 111 (Ohio App. 1945).

14. Malicious prosecution requires cogent proof. Apgar v. Wollston, 43 N.J.L. 57 (1881); Burt v. Smith, 181 N.Y. 1, 73 N.E. 494 (1905); Lipscomb v. Shofner, 96 Tenn. 112, 
substantial. They may include reimbursement for attorney's fees, compensation for injuries to credit or reputation, for loss of use of property, or even for emotional distress, ${ }^{15}$ and any other damages which can be proved to have been proximately caused ${ }^{16}$ by the malicious suit. If the potentially large damages of malicious prosecution were to become the usual or even frequent rather than the exceptional corollary to an ill-fated civil action, a timid or impecunious plaintiff might well hesitate to sue.

In the United States, at least, bona fide litigants have been protected from these risks even at the corresponding risk of encouraging groundless suits. State statutes have minimized the inhibition to potential plaintiffs by severely limiting the costs which may be immediately recovered by a successful defendant to a civil action. ${ }^{17}$ And the courts have reinforced this legislative policy, by holding the action for malicious prosecution in disfavor and imposing a more stringent burden of proof upon its essential elementsmalice and absence of probable cause. ${ }^{18}$ The effect is thus to retard both

33 S.W. 818 (1896); Glenn v. Lawrence, 280 Ill. 581, 117 N.E. 757 (1917); GREEN, JUDGE AND JURY 338 (1930). The absence of probable cause ought to be proven with great clarity. United States Tire Co. v. Kirk, 102 Kan. 418, 170 Pac. 811 (1918). The plaintiff in a civil suit is allowed more latitude than one who institutes criminal proceedings. Pangburn v. Bull, 1 Wend. 345 (N.Y. 1828). But there are temperate suggestions that courts should not carry this policy to an extreme which would deny relief to parties harassed with unjustifiable litigation. Griswold v. Horne, 19 Ariz. 56, 165 Pac. 318 (1917); Jaffe v. Stone, 18 Cal. 2d 146, 114 P. 2d 335 (1941).

15. U.S. Fidelity \& Guaranty Co. v. Miller, 218 Ala. 158, 117 So. 668 (1928) (exemplary damages for injury to feelings); Weaver v. Page, 6 Cal. 681 (1856) (interference with property); Lawrence v. Hagerman, 56 Ill. 68, 8 Am. Rep. 674 (1870) (damage to business and reputation, loss of customers and credit); Foley v. Union House Furnishing Co., $228 \mathrm{Mo}$. App. 1063, 60 S.W. 2d 725 (1933) (injury to person, feelings, and reputation); McInnis v. Atlantic Investment Corp., 137 Ore. 648, 3 P.2d 118 (1931) (attorney's fees in defending malicious suit, damages for deprivation of the use of property).

16. Wandell v. Morley, 4 F. Supp. 193 (M.D. Pa. 1933); Carbondale Inv. Co. v. Burdick, 67 Kan. 329, 72 Pac. 781 (1903); Graffagnini v. Shnaider, 164 La. 1108, 115 So. 287 (1927). It is possible that damage will be presumed when the prior civil suit partakes of a quasi-criminal character with clearly defamatory implications, $e . g$. lunacy or bastardy proceedings. RESTATEMENT, ToRTs $\S 681$, comment $c$ (1938).

17. This is not to say, however, that more liberal cost statutes may not be in order. Courts have noted their insufficiency. Kolka v. Jones, 6 N.D. 461,71 N.W. 558 (1897); Lipscomb v. Shofner, 96 Tenn. 112, 33 S.W. 818 (1896); Closson v. Staples, 42 Vt. 209, 1 Am. Rep. 316 (1869). Taxable costs cover only a fraction of the expenses of litigation. Counsel fees and expenses are allowed in only a few restricted types of cases. Typical statutes are: 28 U.S.C. $\$ 1923$ (Rev. ed. 1948) (allowing \$20 as a docket fee) 17 PURDon's PA. STAT. \$1635 (1930) (allowing three dollars for prosecuting to a judgment). See McCormick, Counscl Fees and Other Expenses of Litigation as an Element of Damages, 5 MinN. L. REv. 619 (1931).

In England costs are assessed by special taxing masters, and may include fees paid to court, to the solicitor, to counsel, and all other necessary expenses. The taxing master operates within the principles prescribed in the Rules of Court. Attorneys' fees must bo itemized and in most cases the maximum for each item is provided by statute. See Goodhart, Costs, 38 YALE L.J. 849 (1929).

18. See note 14 supra. 